\title{
極数変換式交流電動揚貨機について
}

\section{On the Cargo Winch of the Pole Changing Squirrel Cage Motor Type}

\section{細 野 正 巳（神戸商船大学） \\ 武田幸男（”）}

\begin{abstract}
From the measurement of rush current, hook speed, efficiency and the like of the Mitsubishi cargo winch of the pole changing squirrel cage motor type, voltage regulation and loading efficiency are discussed. The essential points are as follows ;

(1) The rush currents at starting and changing notch are about 2 times of the rated current, but when the notch is changed to lower 2 notch from lower 3 notch the rush current is almost 3 times of the rated current is observed, but the duration of those rush currents are the order of 0.5 second in general.

(2) The effect of voltage variation on the moter characteristics is small; the slight increase of current and the decrease of hook speed are observed on the hoist 3 notch.

(3) The loading efficiency of the Pole change winch is nearly equal to that of the Ward-Leonard winch.
\end{abstract}

\section{$\S 1$ 緒—言}

船船の交流化に関しては当初種々の検討が加へられたが、最近の建造船を見れば明らかな如 く、1950年以降の新造船の半数以上は交流船であり、一応交流化に関しては問題がなくなつたか の如く考えられている。

貨物船の交流化の最大の障害であつた甲板補機、特に揚貨機の交流化については、現在ワード レオナード式を多くの船が採用しているが、之は直流に変換して使用するもので交流電動機は直 接使用していない。交流電動機を使用するものとしては、交流整流子電動機又は極数変換式誘導 電動機等の揚貨機が製作されて居り実用されている。

極数変換式が実用になつたのは、昭和11年関釜連絡船金剛丸、興安丸が最初であつたが同揚貨 機は起動電流及び温度上昇の大きい事肪父点とされていたが、其の後改良が加へられ現在に至つ たものである。

筆者等は現在 NYK のS 丸で使用されているものと同型の三菱電機製極数変換式揚貨機につい て実験を行い、又同船での運転状況等について若干の調查をも行つたのでその大要を報告する。 


\section{$\S 2$ 揚貨機の諸特性}

（2-1）揚貨機用誘導電動機について

誘導電動機の回転速度 $N$ は周知の如く、

$$
N=N_{0}(1-s)=\frac{120 f}{P}(1-s)
$$

で表される。茲に $N_{0}$ は同期速度で極数 $P$ 及び電源周波数 $f$ によつて定まり、負荷の增加と共に 滑り $s$ (s】ip) が増加して $N$ は減少する。即ち揚貨機用として異る速度特性を得る為に極数変換 を行うのであるが、その速度特性は本質的に分巻特性であつて無真倚時の最高速度は $N_{0}$ で抑え られる。そして速度変動率及び起動トルクを大きする為、二次抵抗即ち回転子導体抵抗（抵抗 導体を用い特殊構造にしている）を高くとつている。てれは亦一次突入電流の值を減少する事に もなる。

電動機固定子は 2 個の独立した巻線を持ち第 1 ノッチは 16 極 $(1 Y) 、$ 第 $2 、$ 第 3 ノッチは別の 巻線の接続を切換えて 8 極 $(2 Y) 、 4$ 極 $(1 \Delta)$ 它得る様になつている。第 1 図は之等ノッチの切

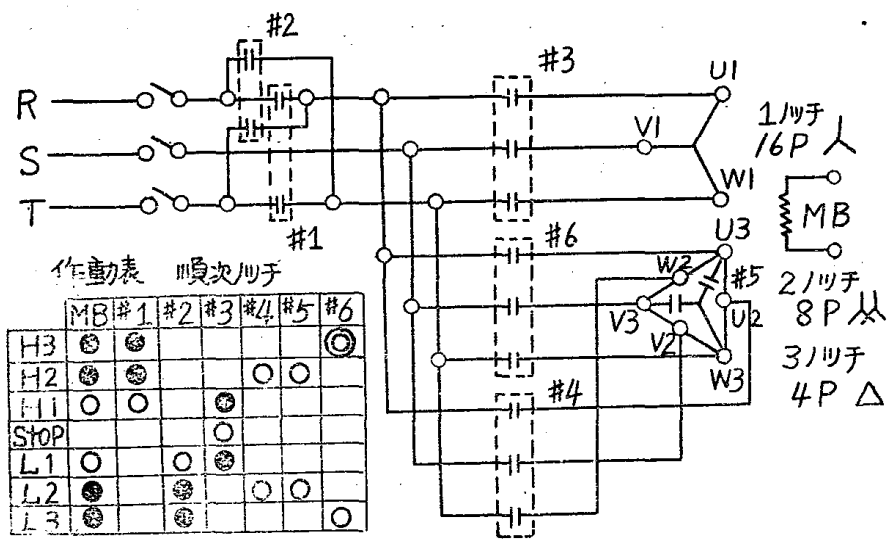

第 1 図 極数変換式の作動
換時の主接触器の作動を示す。

中程度の速度特性は他種の揚貨機とほ ぼ同梂であるが、フック速度が問題とな つた。電動機の同期速度は $f=60$ cycle, $P=4$ として 1800 r.p.m. が最高速度であ つて、定格侍重に対するドラム直径の制 約をうける為フツク速度は抑えられる。 従つてフック速度の堌加を期待するには 荷重が軽量の場合には揚貨機の減速此を 㚆える事以外には、新型 (HSL型) の極 数変換式では歯車二段切替方式を採用し

ている。てれは荷役能率と云う点から特に望まれていた事である。

以下三菱 HWK 型揚貨機の䛲特性を笑験によつて求めた結果を記す。

(2-2) 実験装置

第?2図写真は揚貨機本体及

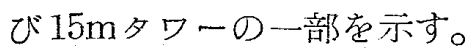
荷重の調節はコンクリートブ ロックの増減によつて行つ た。主幹制御器は左方実験空 内に装置してある。

第 3 㘡は実験装置の配線図 である。 $T_{1}$ は学内変電所の 降圧変压器、 $T_{2}$ は揚貨機専用 の舁圧変压器で二次側タップ により460〜380V の電压を得 る事が出来る。電気量の訫測 は変成器 $(P \cdot T)$ 页で変流器

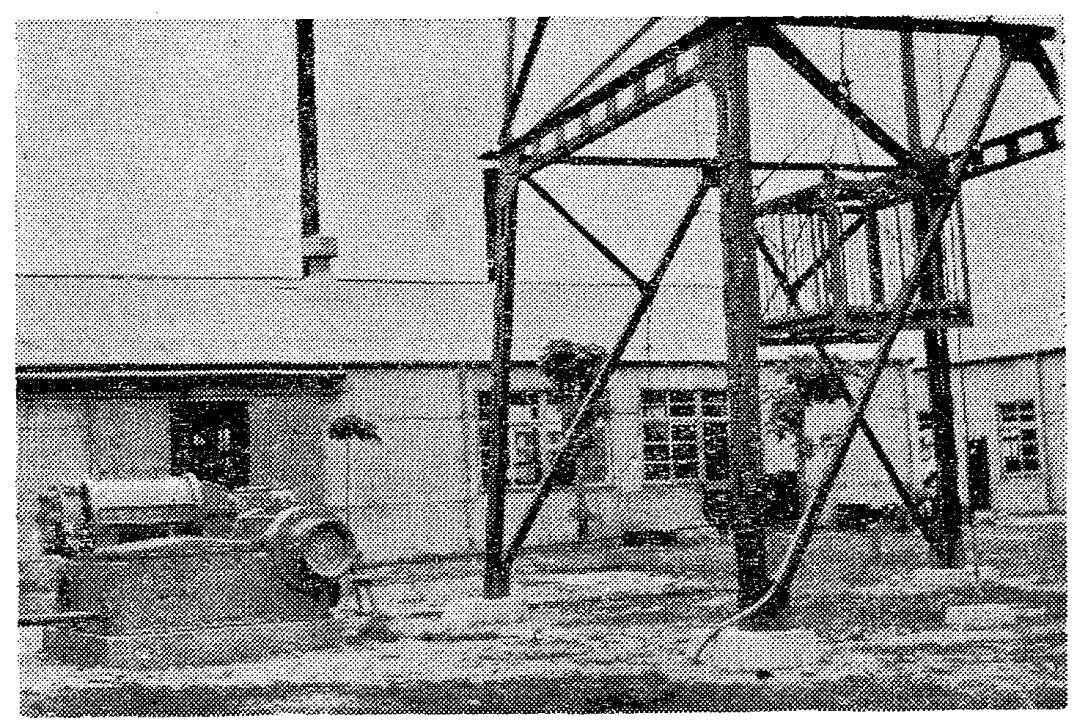

第 2 図 試験用ウインチとタワーの一部 


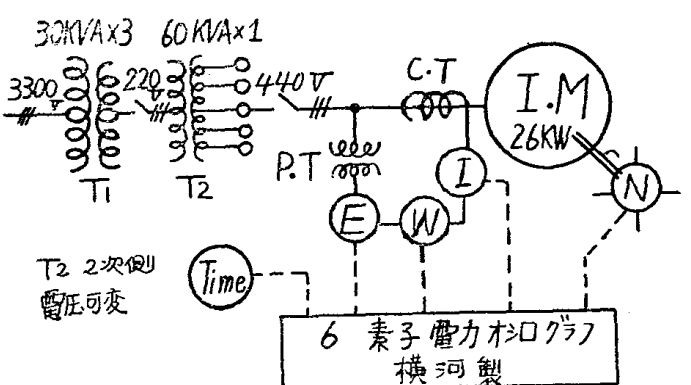

第3図 測 定回 路

（C.T）を介して行い電压、電流、電力測䇥し、 揚貨機のロープ速度を求める為揚貨機ドラムを4等 分した位固に接触子を設け、更に之等の量を電磁才 シロによつて撮影した。

(2-3) オシログラムによる観測

第 4 図a、b は夫及横河製 6 素子パワーオシログ ラフによつて揚げ及び降しノツチに於ける諸量を撮 影したものである。上より時間目盛、回転目盛、電 流、三相電力、端子電圧波形危示す。回転目盛のパ ルス間隔は約 $33 \mathrm{~cm}$ のープ長さに相当し、これと時間目盛とによつて、ロープ速度及び加速度 も求められる。

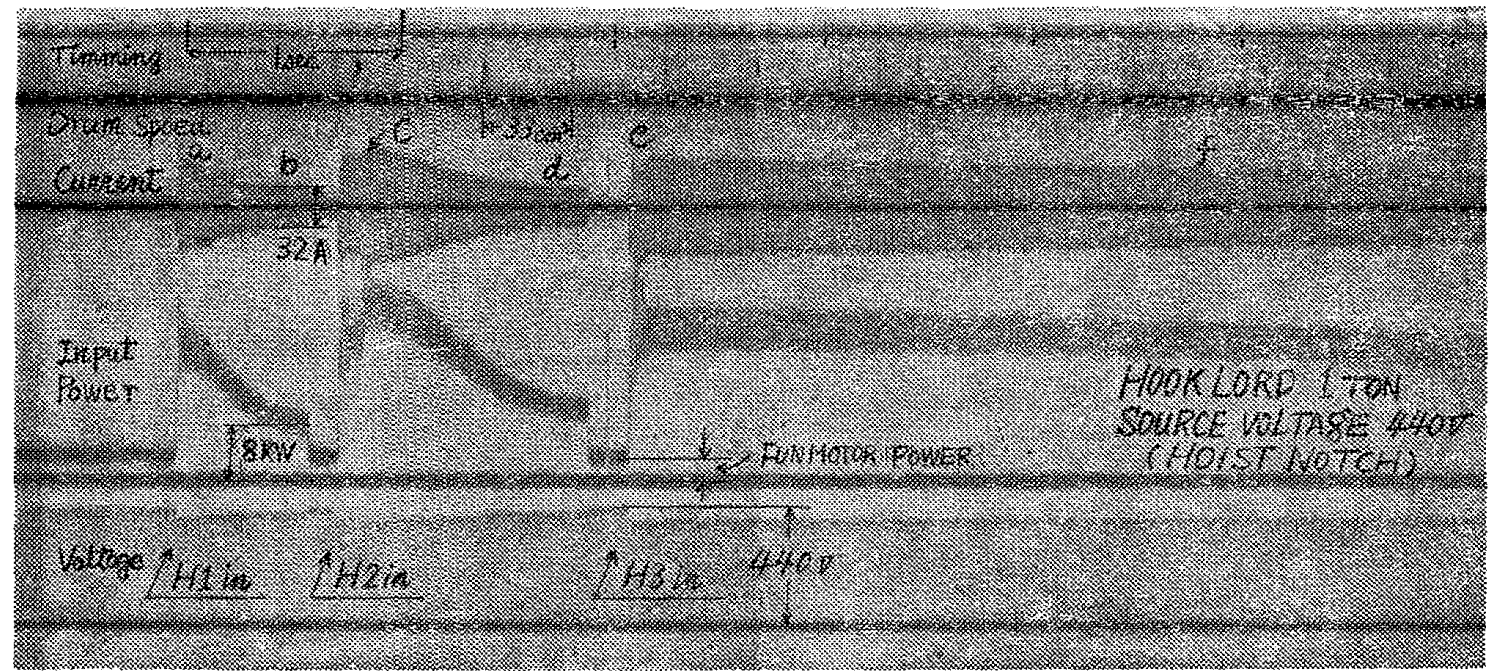

第 4 図 a

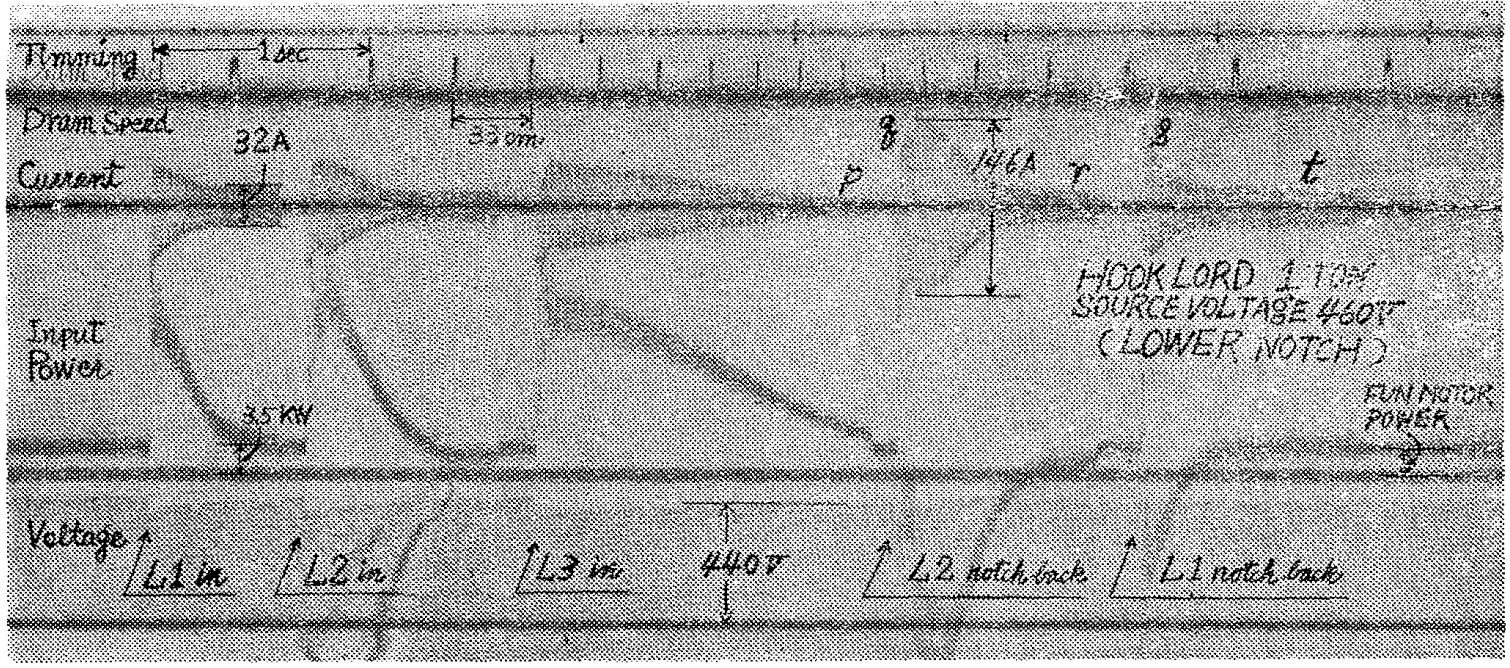

第 4 図 b

図は共に荷重 1ton に対するもので各ノツチの切換時には突入電流が流れ、その為電源電王が

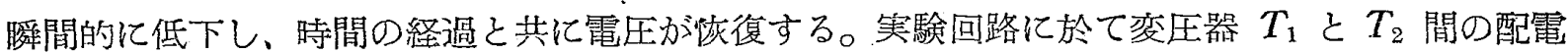
線のインピーダンスドロッブが大きい為(電線長約 $100 \mathrm{~m}$ )、電動機端子電匡の低下が大きく表れ 
ている。

a図は左より揚げノッチ $\mathrm{H} 1 \rightarrow \mathrm{H} 2 \rightarrow \mathrm{H} 3$ と急激にハンドルをとつた場合、b図は下げノッチ L 1 $\rightarrow \mathrm{L} 2 \rightarrow \mathrm{L} 3 \rightarrow \mathrm{L} 2 \rightarrow \mathrm{L} 1 \rightarrow \mathrm{stop}$ とハンドルを急激にとつた場合の各電流、電力、電圧波形で、各ハッ チの切換時に波形の切れ目があるのは、極数変換の為電源を一度遮断する為で、この時間はほぼ $0.1 \sim 0.2 \mathrm{sec}$ である。各荷重に対するオシログラムから突入電流及びその継続時間、ロープ速度 等を唡討する事が出来、更電源電圧の変化した昜合の諸特性も求められる。

（2-4） 起動時及びノッチ切換時の㔖入電流

定格電圧に於ける荷重一速度、電流一速度特性を実測し之を図示すると第 5 四の如くになる。

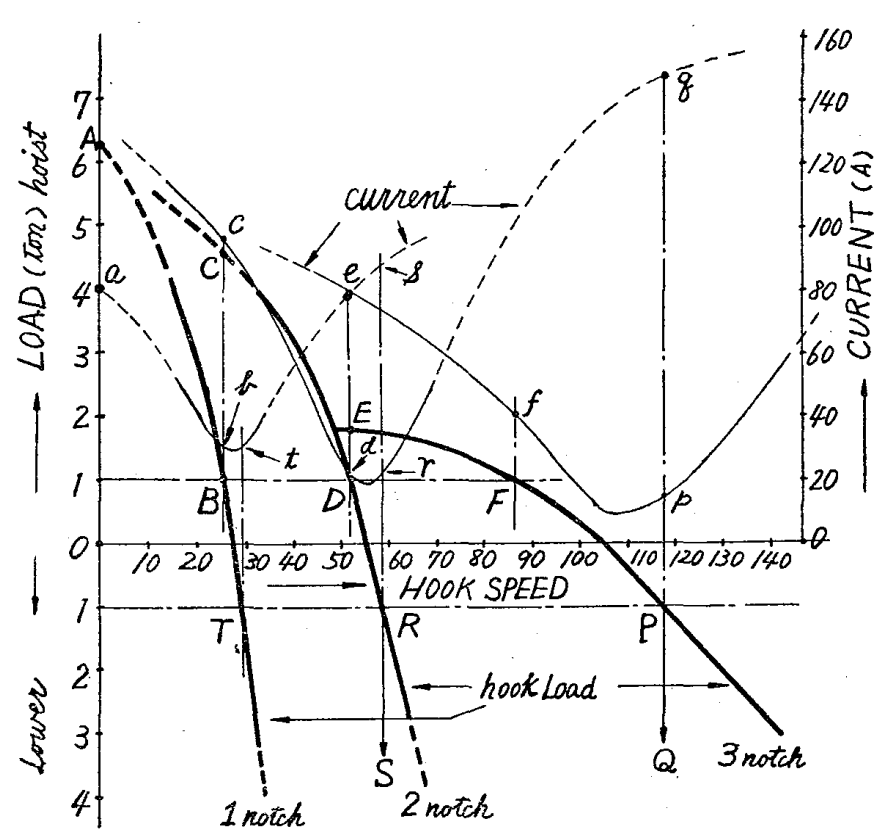

第 5 図 速度一電流、荷重特性 笑線は実測部分、点線は推定部分で電流 曲線中の@印はオシログラムの過渡状態 から求めたものである。ロープ速度の $27.5,55,105 \mathrm{~m} / \mathrm{min}$ は夫及 $1,2,3$ ， ッチによる無負荷ロープ速度を示すもの である。

ての図から定格電圧の下に於ける電流 及び速度の過渡状態並びに定常状態の説 明が出来る。例えば何重 1ton に対する 前揭第 4 図オシロの電流波形を第 5 図に よつて説明する。ノッチ切換による速度 と電動機トルクとの釣合点を $\mathrm{A}, \mathrm{B}, \mathrm{C}$, ……で表し、之等の点に対応する電流值 を夫々 $\mathrm{a}, \mathrm{b}, \mathrm{c}, \cdots \cdots$ で表す。第 4 図の記 号はての意味である。叉トルクは揚貨機 ドラムの直经が一定であるから、 $\mathrm{kg}-\mathrm{m}$ 相当の ton 数で表す。ノッチを stop より H3 急激に進めた時各動作值を示すと第 1 表の如く になる。

第1表 上げノツテに於ける突入電流（荷重 1ton）

\begin{tabular}{|c|c|c|c|c|c|c|}
\hline , & \multicolumn{2}{|c|}{$\mathrm{H} 1$} & \multicolumn{2}{|c|}{$\mathrm{H} 2$} & \multicolumn{2}{|c|}{$\mathrm{H} 3$} \\
\hline & 起 動 & 定賞 & 起 動 & 定 常 & 起 動 & 定 常 \\
\hline 動 作 点 & A & B & $\mathrm{C}$ & $\mathrm{D}$ & $\mathrm{E}$ & $\mathrm{F}$ \\
\hline 速度 $(\mathrm{m} / \mathrm{min})$ & 0 & 28 & 28 & 51 & 51 & 86 \\
\hline$ト ル ク(\operatorname{ton})$ & $6^{*}$ & 1 & $4.2^{*}$ & 1 & 2 & 1 \\
\hline 電 流 $(\mathrm{A})$ & 80 & 32 & 97 & 27 & 82 & 41 \\
\hline
\end{tabular}

註 *印は推定值を表す。

先づ H1 が入ると（a，A点）起動電流 80A が流れ、約 6ton の起動トルクで起動し曲線 $\mathrm{ab}$, ABに沿つて変化し、 $\mathrm{b}, \mathrm{B}$ 点 $(\mathrm{I}=32 \mathrm{~A}, \mathrm{~N}=28 \mathrm{~m} / \mathrm{min})$ で 1 ton の荷重と釣合う。H1 が平衡した後 H 1 が切れ H2 が入ると I は H2 特性曲線上に移る。之が H2 に於ける突入電流で c点 (97A) が てれを示す。荷重以約 4.2tonのトルク（C点）で加速され $d, D$ 点 $(I=27 \mathrm{~A}, \mathrm{~N}=51 \mathrm{~m} / \mathrm{min})$ で 
再び釣合う。 $\mathrm{H} 2$ が切れ $\mathrm{H} 3$ が入ると動作点は $\mathrm{e}, \mathrm{E}(\mathrm{I}=82 \mathrm{~A})$ 亿移り荷重は約 2 ton のトルクで 加速され I は減衰して $\mathrm{f}, \mathrm{F}$ 点 $(\mathrm{I}=41 \mathrm{~A}, \mathrm{~N}=86 \mathrm{~m} / \mathrm{min})$ で釣合の状態に入る。

降し L1，L2，L3 の場合き電動機の回転方向が逆になる事と、電力回生の為に定常電流值が減 少する事をのぞけば揚げノッチの場合とほぼ同様である。電力波形に於て仆止時の電力消費は送 風機及び制御回路入力を示すもので，降しノッチに於て此の線より下側に出ているのは電力回生 が行われている為である。

L3 $\rightarrow$ L2 の切換の瞬間は電動機の発生電圧は電源周波数の約 2 倍の周波数を持つて居り、誘導 発電機として電力回生を行う。第 4 図bで電力が大きな負值を示しているのは此の状態を表わし

第 2 表 下しノッチバックに於ける然入電流 (1 ton)

\begin{tabular}{|c|c|c|c|c|c|c|c|}
\hline , & L 3 & \multicolumn{2}{|c|}{ L 2} & \multicolumn{4}{|c|}{ L 1} \\
\hline & 定常 & 起 動 & 定常 & 起 & 動 & 定 & 常 \\
\hline 動 作 点 & $\mathrm{P}$ & Q & $\mathrm{R}$ & & & & $\Gamma$ \\
\hline 速度 (m/min) & 117 & 117 & 58 & & 58 & & 28 \\
\hline トルク (ton) & 1 & $\triangle$ & 1 & & $\triangle$ & & 1 \\
\hline 電 流* (A) & 12 & 146 & 23 & & 88 & & 30 \\
\hline
\end{tabular}

註 *電流值は㛬導発電機としての返還電流を示す。

$\triangle$ トルクの值不明。

ている。然し此の時の突入電流は 146A 亿達し、負荷が大きい時には、over load Relay が作動 して stopする事がある。

第 2 表にノッチバックに於ける突入電流、制動トルク等を示している。L2へ切換えた瞬閒の制 動トルク Q 点はPから重㨁に下した線と L2 特性曲線との交点にあつて図には表われていない。 そして電流は $\mathrm{q}$ 点 $(146 \mathrm{~A})$ から $\mathrm{r}$ 点に減少して釣合う。ノッチバックに於ける突入電流は極数 変換式固有のもので、電源沉与える影響は最も大きい。

第 3 表は定格電圧に於ける焱入電流、定常電流值を各種荷重に対して求めたものである。順次

第 3 表 突入電流と減亭 時間

\begin{tabular}{|c|c|c|c|c|c|c|c|c|c|c|c|}
\hline \multirow[t]{2}{*}{ 荷 } & \multirow{2}{*}{ ton } & \multirow{2}{*}{$\begin{array}{l}\text { ノッチ } \\
\text { 番 号 }\end{array}$} & 巻 & 上 & げ & 巻 & 下 & L & \multicolumn{3}{|c|}{ 巻下しノッチバック } \\
\hline & & & $\mathrm{I}_{\delta}$ & $I$ & $\mathrm{~T}$ & $\mathrm{I}_{\delta}$ & I & $\mathrm{T}$ & $\mathrm{I}_{\boldsymbol{\delta}}$ & I & $\mathrm{T}$ \\
\hline \multirow{3}{*}{\multicolumn{2}{|c|}{0.1}} & 1 & 76 & 33 & 0.3 & 72 & 28 & 0.3 & 85 & 28 & 0.2 \\
\hline & & 2 & 85 & 25 & 0.45 & 72 & 22 & 0.5 & 135 & 22 & 0.4 \\
\hline & & 3 & 72 & 12 & 1.6 & 60 & 12 & 4 & & & \\
\hline \multirow{3}{*}{\multicolumn{2}{|c|}{1.5}} & 1 & 85 & 36 & 0.3 & -72 & -32 & 0.2 & -90 & -32 & 0.3 \\
\hline & & 2 & 103 & 36 & 0.8 & -72 & -25 & 0.3 & -154 & -25 & 0.5 \\
\hline & & 3 & 83 & 60 & 0.5 & -68 & -22 & 1.3 & & & \\
\hline \multirow{3}{*}{\multicolumn{2}{|c|}{3}} & 1 & 80 & 45 & 0.6 & -76 & -34 & 0.25 & -90 & -34 & 0.3 \\
\hline & & 2 & 110 & 60 & 3 & -57 & -35 & 0.3 & -159 & -35 & 0.5 \\
\hline & & 3 & & & & -62 & -53 & 0.8 & & & \\
\hline
\end{tabular}

註 1 電流の㑑值は語導発電機としての返還電流を示す。

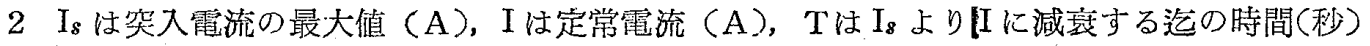




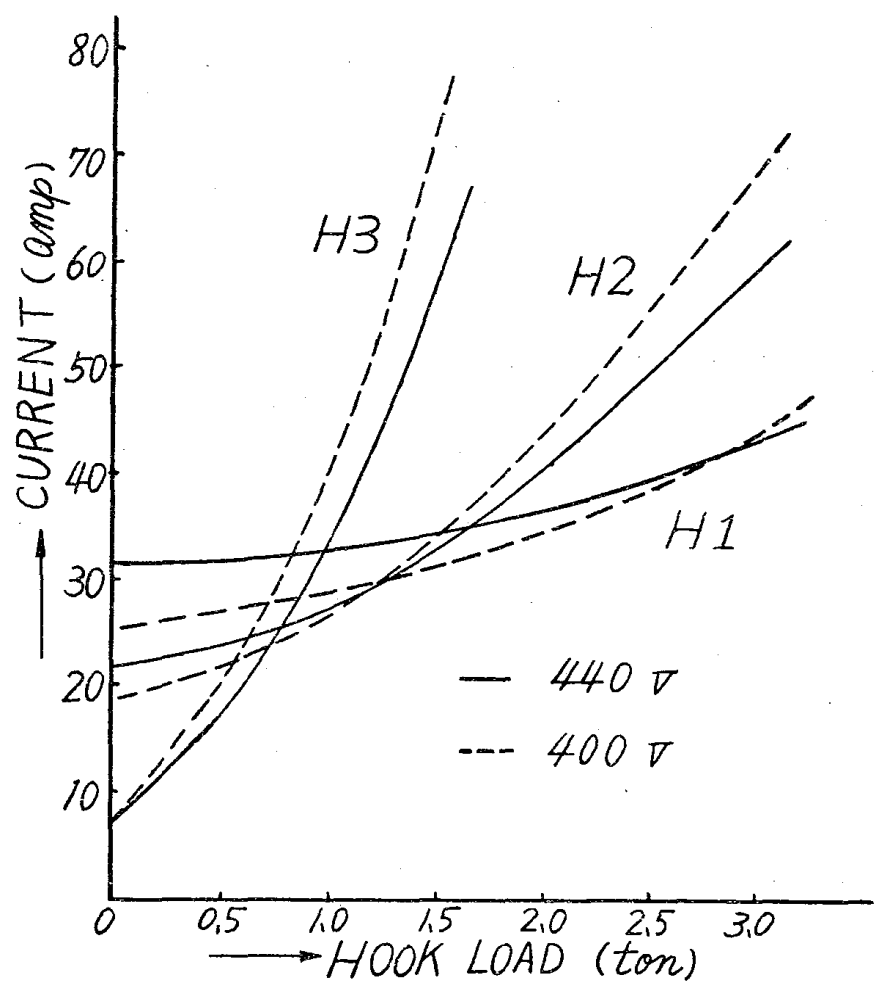

第 6 図 電圧変化による荷重一電流特泾

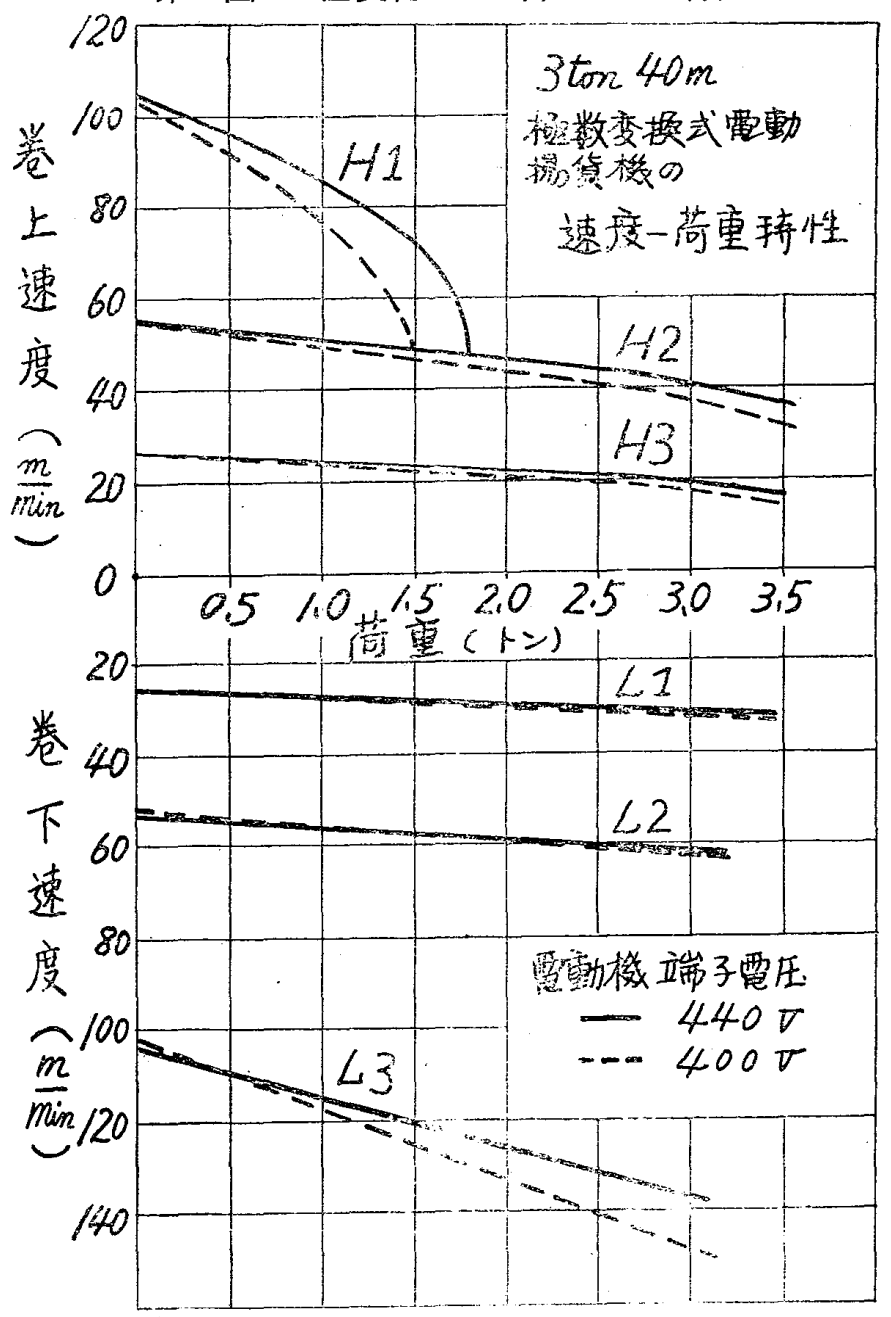

第 7 図 電圧低下時の速度荷重特烍
揚げ入は降しノッチに於ける突入電流 は、定常值の約 2 倍でその継緬時間は 約 $1 \mathrm{sec}$ 考考慮すれば良い。然し。 L3 $\rightarrow$ L2 亿於称る值は定格值の約 3 倍 であつて、嗬重の変動はあつてもとの 值に大きな変化はない。

（2-5）電压変動時の荷重一一定常 電流特性

掦貨機端子電压の低下が電流に与える 影響を実測したが、その結果を第 6 図 に示す。乙れは第 2 図の変圧器 $\mathrm{T}_{2}$ の 二次側タップを変えて求めたものであ る。図では定格電圧の約10\%の低下に 対するものと比較して表しているが、 その結果を要約すると次の様である。 即電圧の低下に対し

(1) H1 では軽負渮程定常電流が減少 する。

（2）H2 では待重が 1.5ton をてえる と電流は堌加する。

（3） H3 では荷重の増加する程電流の 増大は激しい。

(4) 降しノツチでは電力回生が行われ る為電流值は減少し、電流の位相は 逆になる。

（5）突入電流に対してもほばてれと同 椂な傾向が見られる。

（2-6） 電圧変動時のッープ速度特 性

揚貨機のロープ速度について前と同 㥞の方法で電圧変動時の特性をも求め た。第 7 図に於て定格電圧に $440 \mathrm{~V}$ に 対するものを策線で $400 \mathrm{~V}$ の場合を点 線で表しているが、H1，H2 では約 5 $\%$ ，H3で $10 \%$ 程度、特にH3で1.5ton 附近では電圧低下の影響が大きく20\% 程度の速度低下が起る。後述の如く船 内電源の変動は約士 $5 \%$ 以内之考えら れるので此の程度ではロープ速度の变 動は殆んどないと考えられる。降しノ 
ツチに於ては殆んど速度変化なくL３亿於て荷重大なる場合に速度の増加が若干認められる。 (2-7) 能率

各河重に刘し各ノッチ每に入力及びロープ速度を計測して之等から出力及び能率を求めたが、

第 4 表 $\mathrm{H}$ 力及能率特 性

\begin{tabular}{|c|c|c|c|c|c|c|c|c|c|}
\hline \multirow{3}{*}{ ノッチ } & \multicolumn{2}{|c|}{ 害 } & 测 & \multicolumn{2}{|c|}{ 值 } & \multicolumn{2}{|l|}{ 阡 } & \multicolumn{2}{|r|}{ 值 } \\
\hline & 線間電压 & 線䍚流 & 入 力 & 荷 重 & |ロープ速度 & 力 率 & 出 & 力 & 能 率 \\
\hline & V & A & $\mathrm{k} \cdot \mathrm{W}$ & ton & $\mathrm{m} / \mathrm{min}$ & $\%$ & $\mathrm{~kW}$ & $\mathrm{P}$ & $\%$ \\
\hline \multirow{7}{*}{ H 1} & 446 & 32.3 & 2.7 & 0 & 25.0 & 10.8 & 0 & 0 & 0 \\
\hline & 440 & 32.0 & 5.3 & 0.5 & 24.0 & 21.8 & 2.0 & 2.6 & 37.0 \\
\hline & 450 & 33.4 & 8.0 & 1. 0 & 23.1 & 30.8 & 3.8 & 5.05 & 47.2 \\
\hline & 450 & 35.2 & 11.2 & 1.5 & 22.3 & 46.7 & 5.5 & 7.3 & 48.8 \\
\hline & 450 & 37.5 & 12.4 & 2.0 & 20.6 & 49.0 & 5.8 & 7.8 & 46.8 \\
\hline & 454 & 40.0 & 17.6 & 2.5 & 19.0 & 57.4 & 7.9 & 10.6 & 44.8 \\
\hline & 430 & 44. 3 & 21.2 & 3.0 & 19.0 & 64.5 & 9.3 & 12.4 & 43.8 \\
\hline \multirow{7}{*}{$\mathrm{H} 2$} & 454 & 22.4 & 2.5 & 0 & 51.0 & 14.0 & 0 & 0 & 0 \\
\hline & 442 & 23.1 & 7.4 & 0.5 & 49.0 & 41.8 & 4. 1 & 5.5 & 55.2 \\
\hline & 449 & 27.6 & 12.8 & 1.0 & 48.0 & 59.8 & 7.8 & 10.4 & 60.7 \\
\hline & 440 & 34.0 & 18.8 & 1.5 & 45.7 & 72.5 & 11.2 & 15.0 & 59.6 \\
\hline & 446 & 40.3 & 24.0 & 2.0 & 44.0 & 77.0 & 14.6 & 19.6 & 60.6 \\
\hline & 451 & 51.4 & 34.6 & 2.5 & 42.0 & 86.1 & 17.2 & 23.0 & 49.6 \\
\hline & 410 & 64.3 & 37.6 & 3.0 & 37.0 & 72.0 & 19.0 & 24.1 & 48.0 \\
\hline \multirow{4}{*}{ H 3} & 460 & 7.2 & 3.3 & 0 & 99.0 & 57.5 & 0 & 0 & 0 \\
\hline & 447 & 18.9 & 13.4 & 0.5 & 95.0 & 91.6 & 7.6 & 10.2 & 56.8 \\
\hline & 445 & 35.0 & 26.0 & 1. 0 & 78.0 & 96.3 & 13.8 & 19.5 & 41.8 \\
\hline & 440 & 62.6 & 39.2 & 1.5 & 56.0 & 84.2 & 13.7 & 18. 4 & 35. 1 \\
\hline
\end{tabular}

その結果を第 4 表に示す。出力及び能率はギャー系統、滑車等の損失を含めた数值であつて、各 負荷に刘してほぼ一定の值を有している。

第 5 表 荷役時の温度上昇

\begin{tabular}{|c|c|c|c|}
\hline 測 & E 日 & 31. 6. 6晴 & 31. 6.9晴 \\
\hline \multirow{2}{*}{${ }^{\circ}{ }^{\circ} \mathrm{C}$} & 日 影 & 30 & 34 \\
\hline & 直 射 & 35 & 43 \\
\hline 揚 & 3 & 57 & \multirow{13}{*}{$\begin{array}{l}68.5 \\
54.5 \Delta \\
77.5 \\
68 \\
50 \triangle \\
54 . \triangle \\
73.5 \\
57 \\
68 \\
59\end{array}$} \\
\hline 貨 & 4 & 57 & \\
\hline 機 & 5 & 53 & \\
\hline 番 & & & \\
\hline 号 & $\begin{array}{l}07 \\
\circ\end{array}$ & & \\
\hline$\widehat{0}$ & 8 & & \\
\hline 印 & 10 & $43 \triangle$ & \\
\hline は & 13 & & \\
\hline 检楼 & 14 & 68 & \\
\hline 唯 & 15 & 75 & \\
\hline 拓 & 16 & & \\
\hline 式 & 17 & 59 & \\
\hline & 18 & 58 & \\
\hline
\end{tabular}

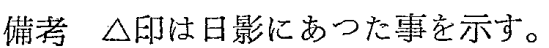

\section{§3 S 丸に於ける使用状態}

$\mathrm{S}$ 丸は昭和31年 5 月就航したが筆者等は32年 6 月迄の約 1 年間の 極数変換式揚貨機 の 使 用 実績を調查した。同船はレオナード式揚貨機 （三菱製）14台と極数変換式 4 台を装備してい る。

\section{（3-1） 温度上昇 ${ }^{1)}$}

第 5 表はレオナード式及び極数変換式の温度 上昇を笑測した結果で、ブレーキケースに於て 測定した数值である。（ての部分の温度上昇が 最大であつた。)

温度上昇は荷重の種類、ノッチの進め方等に よつて異るものであつて、其の後の荷役に於て も絶えず注意が払われたが、レオナード式、極 
数変換式共に温度上昇はほぼ $30^{\circ} \mathrm{C}$ 程度であつた。

(3-2) 電源電圧の変動 ${ }^{2}$

$\mathrm{S} 丸 に$ 於て荷役中、主配電盤に於て計測した電圧変動の 1 例を第 6 表に示す。

第6表 実船に於ける電源変動

\begin{tabular}{|c|c|c|c|c|}
\hline \multicolumn{2}{|c|}{$\begin{array}{l}\text { 使 用 発 電 機 台 数 } \\
\text { (定格 } 225 \mathrm{~K} \text { V A) }\end{array}$} & 2 & 1 & $2^{*}$ \\
\hline \multirow{2}{*}{$\begin{array}{l}\text { 使用揚貨機 } \\
\text { 台 数 }\end{array}$} & レオナード式 & 12 & 6 & 10 \\
\hline & 極数変換式 & 4 & 2 & 0 \\
\hline \multirow{5}{*}{ 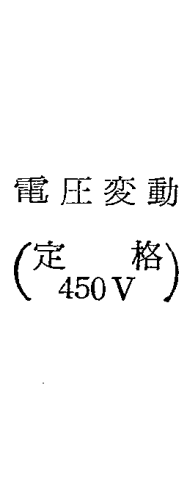 } & 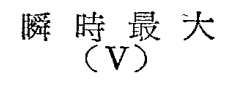 & $350 \sim 500$ & $360 \sim 430$ & $410 \sim 460$ \\
\hline & 同 $(\%)$ 上 & $22 \sim 7$ & $20 \sim 6.6$ & $9 \sim 2$ \\
\hline & $\begin{array}{l}\text { 瑟められた } \\
\text { 回 }\end{array}$ & 1日3回 & 1 日 2 回 & 1 時間に 1 回 \\
\hline & 平 $(V)^{\text {均 }}$ & $430 \sim 465$ & $430 \sim 460$ & $430 \sim 455$ \\
\hline & 同 $(\%)^{\text {上 }}$ & $4.5 \sim 3.7$ & $4.5 \sim 2$ & $4.5 \sim 1.1$ \\
\hline \multicolumn{2}{|c|}{ (電 ${ }^{\text {定 梳 }}$ 360A) } & $\left(\begin{array}{ll}110 \sim 245 \\
\text { NO.1 G })\end{array}\right.$ & $230 \sim 335$ & $\begin{array}{l}120 \sim 220 \\
\left(\begin{array}{ll}\text { NO.1 } & \text { G }\end{array}\right)\end{array}$ \\
\hline
\end{tabular}

註 *印は同型船による実測值を示す。

16台揚貨機中、極数換式は 4 台である為、之の影響を充分把握する事は困難であるが、レオナ ード式のみの運転状態では約 $4 \%$ 程度の電圧降下があるのに対し、極数変換式を併用した a11 hatch の状態では平均 $4 \%$ 、最大瞬間 $20 \%$ 程度の電圧低下は一日数回認められている。然し配 電盤での計器の読みには針のふれ過ぎがある為、実際には10数\%程度のものと考えられる。

(3-3) 故 障

現在迄に約千時間程度使用されているがての間熱帯地域でも使用されて居り、相当の温度に上 梨したが支障はなかつた。取扱者によつて特に留意された点は主コンタクトのスパークによる焼 損と、OLR の Dush pot の調整であつたが、事故は報告されて居らず、保守の点からはむしろ レオナード式よりも有利と認められている。

\section{$\S 4$ 考察}

\section{(4-1) 荷重一能率特性}

極数変換式の能率特性は一般の直流揚貨機と比較して若干異つている。第 8 図は三井造船秼式 会社に 5/3ton，25/41m/min の蒾車二段切替淔流揚貨機の能率の実測を依頼した結果（実線） と筆者等が極数変換式について実測した第 4 表の結果 (点線) とを此較したもので、その是格等 異る点は多いが傾向は此較出来る。

一般に直流揚貨機认於ては低速ノッチでは電機子直列抵抗による電力損失が大きい為当然低能 率となりノツチが進むに従つて高能率となる。然し極数変換式では斯様な抵抗損失はなく、極数 の切換えで変速を行う為能率はほぼ50〜60\%程度で大きな変化はない。 


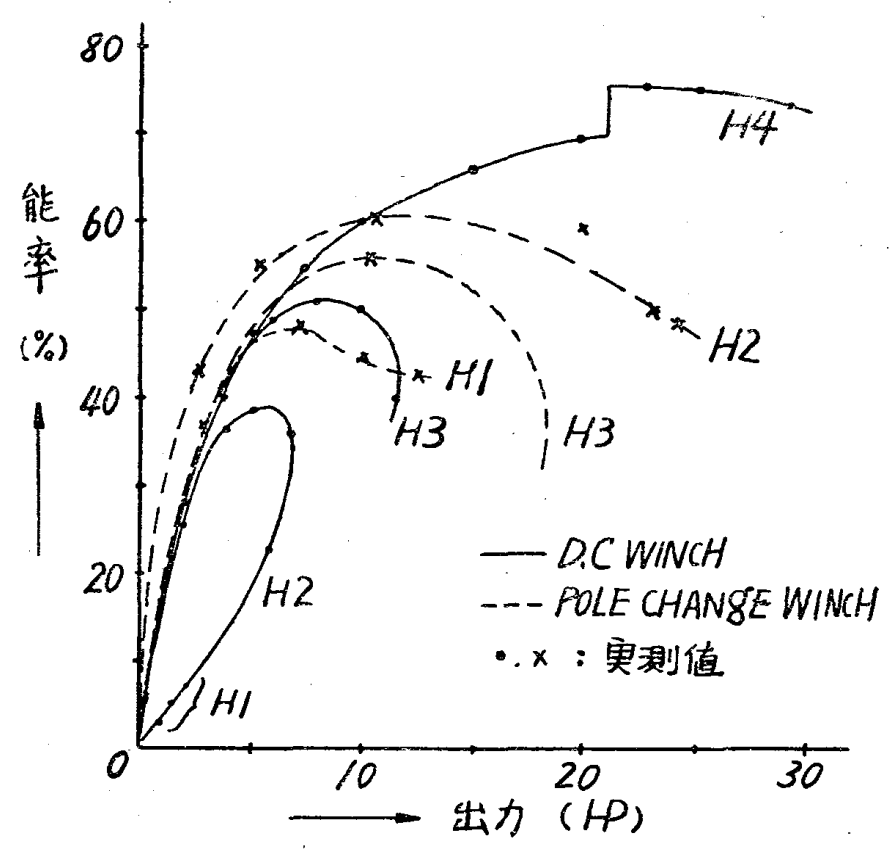

第 8 図王力一能率特性
（4-3）電压変動と電源の速応性 誘導電動機は起動電流が大きく、之に よる電源の安定が屢々論ぜられる。即ち 多数の揚貨機によるノッチ切搝の重なり に対して電源発電穖の自動電压調整器が 応じきれず顀嗬によつて絶えず電圧変動 を伴い、乙の為 Hunting を起し易いと されている。ての問題については起動電 流の大きさとその継続時間と電源発電機 ○速応性（電压恢復特性）の2点に分け て検討する必要がある。

極数変換式を併用した殉合の電圧変動 に関しては第 6 表の示す通りであるが、 レオナード式のみで荷役を行つた歾合の 電压変動の状況は S 丸では充分調查出来 なかつた。然し同型船（全レオナード式

揚貨機16台）に於て実測した結果では電圧変動は平均 $4 \%$ 程度のもので僢間最大変動は土10\%程 度のものが屢及認められて居る。極数変換式を 4 台併用すると電圧変動並びに電流変動がやや目 立つが、此の程度では合若干極数変換式を多く採用しても、現在の電源及び自動電圧調整器（三 菱製 S R-4 F 型) で以て充分使用に耐えうると思われる。

電源の速応性を高める点については最近特に此の方面の研究の機運が高まつて居り、例えば磁 気増幅器或は特殊回転堌幅器を使用した速応励磁方式又は励磁機なし速応版磁、更に交流複巻式 等の試みが為されて居り、電源変動に対する改善も可能であつて極数変換式揚貨機の使用に対す る電源変動も解決される事と思われる。

\section{(4-4) 荷 役 能 率}

極数変換式の速度特性は分巻特性であつて速度調節は困難である。又無負荷速度は電動機の同 期速度で制約される為、例えば H2 で定格荷重 3ton $40 \mathrm{~m} / \mathrm{min}$ のロープ速度が無負荷では $55 \mathrm{~m}$ $/ \mathrm{min}$ であつて約 $30 \% の$ 速度覀動率しか得られない。又 H3での最高速度即ちフック速度は $105 \mathrm{~m}$ /min で之をレオナード式と比較すると約 $2 / 3$ 程度である。ての為極数変換式は綜合的に荷役能 率肪劣ると云われている。然し実際には他の型式のものと此較するとしてもその方法に困難を伴 ふ事が多い。

筆者等は JIS 亿定められている直流揚貨機の組合せ荷重試験 ${ }^{2)}$ の要領で、 $20 \mathrm{~m}$ を 1.5 ton の負 荷で上下し、後無負渮で 20 mを上下する様な 1 サイクルの所要時間を求めた。その方法は各ノッ チに於てロープ長約 $13 \mathrm{~m}$ 迄 (此の附近では速度は一定の状態にある。) の時間一速度特性を求 め、之を㱏長して $20 \mathrm{~m}$ 迄の所要時間を求めた。第 7 表の A.C とあるのはてれである。又同表に 於けるD.C (三菱製直流揚貨機3ton, $40 \mathrm{~m}, 4$ ノツチ) の荷役所要時間は同社から発表されている 実測值を基として、速度特性曲線より求めたものである。即ちAは1.5tonを最高ノッチ（A.Cは H3，D.Cは H4) で $20 \mathrm{~m}$ を上下した場合，換言すれば 1.5 ton に対する最小何役時間を示すもの である。同様に B は定格荷重 $3 \operatorname{ton}$ の場合、Cは 1.5 ton を定格ノッチで上下した場合であつて、 極数変換の方が $10 \sim 20 \%$ 程度大きく出ている。

然し実際の荷役を考えて見ると普通荷役の duty cycle は 1 分半に 1 回程度で、上の例で云え 
第 7 表 荷役時間 の此較

\begin{tabular}{|c|c|c|c|c|c|c|c|c|c|}
\hline \multirow{2}{*}{$\begin{array}{l}\text { 試験 } \\
\text { 番号 }\end{array}$} & \multirow{2}{*}{$\begin{array}{l}\text { 荷 重 } \\
\text { (ton) }\end{array}$} & \multirow{2}{*}{ 揚貨機 } & \multirow{2}{*}{$\begin{array}{l}\text { ハッチ } \\
\text { No. }\end{array}$} & \multicolumn{2}{|c|}{ 荷 } & \multicolumn{3}{|c|}{ 間 (秒) } & \multirow{2}{*}{$\begin{array}{c}\text { 百分率比 } \\
\%\end{array}$} \\
\hline & & & & 荷重上 & 荷重下 & フフック上 & フック下 & 計 & \\
\hline \multirow{2}{*}{ A } & \multirow{2}{*}{1.5} & D. C & 4 & 14.6 & 10.0 & 11.0 & 10.2 & 45.8 & 100 \\
\hline & & A. $\mathrm{C}$ & 3 & 15.8 & 9.8 & 12.4 & 11.3 & 52.3 & 113 \\
\hline \multirow{2}{*}{ B } & & D. C & 3 & 29.4 & 13.0 & 11.0 & 10.2 & 63.6 & 100 \\
\hline & & A. C & 2 & 27.6 & 19. 0 & 12.4 & 11.3 & 70.9 & 110 \\
\hline \multirow{2}{*}{ C } & \multirow{2}{*}{1.5} & D. C & 3 & 22.7 & 13.8 & 11.0 & 10.2 & 57.7 & 100 \\
\hline & & A. C & 2 & 26.0 & 21.0 & 12.4 & 11.3 & 70.7 & 123 \\
\hline
\end{tabular}

備考 (1) $\{$ D. C : 三菱製直流揚貨機 3ton 40m 4ノツチ A.C : 三菱製極数変換式 3ton $40 \mathrm{~m} 3$ ノツチ

(2) フツク上、下は共に最高ノッチによる。

ば約 20〜30 秒程度の休止時間があるから、これを考慮すると実際の荷役時間の比は更に接近す

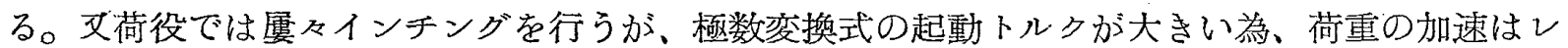
オナード式より遙に早く、ての為 $5 \mathrm{~m}$ 程度の揚げ降しを比較すると、極数変撸式の方が所要時間 が短く、従つて之等を綜合して实際の何役所要時間を検討すれば両者の差は殆んどなくなる。S 丸に於てもレオナード式と㴍数変換式との荷役時間を殆んど問題にしていないのも上記の如き理 由によるものである。

\section{(4-5) 艤装上の問題}

交流化の当初極数変換式の利点として艤装上の問題があげられていたが、てれについても若干 ふれておきたい。要点を重量、据付面積、価格にとどめ各種揚貨機について比較すると第 8 表の 如くなる。

第 8 表 艤装上から見た交流揚貨機の比較

（揚貨機定格 3ton $36 \mathrm{~m}$ )

\begin{tabular}{|c|c|c|c|c|}
\hline & 全 $\underset{\text { (ton) }}{\text { 重 }}$ & $\begin{array}{l}\text { 据付面皘 } \\
(\mathrm{cm} \times \mathrm{cm})\end{array}$ & 価 $(\%)$ 格 & 侟 \\
\hline レオナード式 & $\begin{array}{c}\text { 約 } 4.2 \\
\text { (台盤銅板) }\end{array}$ & $145 \times 136$ & 100 & $\begin{array}{l}\text { 据付面積に } \\
\mathrm{M}-\mathrm{G} \text { 室を } \\
\text { 含まず }\end{array}$ \\
\hline 極 数 変 換 式 & 約 3.5 & $146 \times 140$ & $65 \sim 85$ & \\
\hline 整流子電動機式 & $\begin{array}{l}\text { 葯 } 3.7 \\
\text { (台盤鋼板) } \\
\text { 約 } 4.5 \\
\text { (台船鋳物) }\end{array}$ & $150 \times 165$ & $85 \sim 95$ & $\begin{array}{l}\text { 新コンプレ } \\
\text { ックス型 }\end{array}$ \\
\hline
\end{tabular}

之等の数值は機器の改良と量産等によつて変るものであるが一応比較の目度とする事が出来よ う。極数変換式が之等の各々について利点を有しているのは明かであるが、特にその洒格の安俩 な事は船価の低減と云う点から見て大きな魅力であろう。

\section{$\S 5$ 結語と謝辞}

以上述べた点を要約すると次の様である。 
(1) 極数変換式の突入電流は、起動時は定格電流の約 2 倍程度であるが L3 から L2 へのノッ チバックの場合に定格電流の約 3 倍程度が流れる。然しその継続時間は約 0.5 秒程度である。

(2) 電源電圧の変動はレオナード式に比べて若于大きいが、これに附随して電源発電機の速応 性も検討される可きである。

（3）電源電圧低下による揚貨機の特性変化は少く、H3、1.5ton 附近に於て若干電流の増加と 速度の低下が認められたに過ぎない。

（4）動作状態の全般に於て $50 \%$ ６0\%程度の能率を持つて居り、直流揚貨機の能率が変化する のと対象的である。

(5) フック速度はレオナード式と比較して低いが、加速時間が短い為に実際の荷役能率は殆ん ど等しい。

（6）重量、据付面積、価格等、艤装上の点から見れば各種揚貨機中最も有利である。

（7）制御機構の簡単な事は事故の発生を少くし、保守を容易ならしめる事も見逃し得ない利点 である。

従来極数変換式は電源変動と荷役能率の点でその価值が過少評価されていた嫌があり、極数変 換式に対する娭討が各造船会社及び船会社に於て一層為される可きではないかと考えられる。

終りに当り種々資料を提供され御教示を戴いた N.Y.Kさ双き丸藤山機関士並びに同社海務課 の諸氏、有益な資料を戴いた三菱電機長崎製作所技術部、及び三茾造船電気設計課の諸氏に対し 謝意を表する次第であります。又御検討を戴いた本学海津教授、実験に拹力して戴いた東技官、 卒業研究として実験を担当した松村攀久君、長尾陽太郎君、黒田俊介君に併せて感謝の意を表す る次第であります。

文献 1) さ好き第一次航就航報告 N Y K海務部

2) JIS F6702. 5.4. 